\title{
Initial sexual maturity and fecundity of the goldfish Carassius auratus (Perciformes: Cyprynidae) under semi-controlled conditions
}

\author{
A.A. Ortega-Salas ${ }^{1} \&$ H. Reyes-Bustamante \\ 1 Instituto de Ciencias del Mar y Limnología, UNAM. Calzada Joel M. Camarena s/n, Mazatlán 82240, Sinaloa Apdo. \\ Post: 811, México; ortsal@mar.icmyl.unam.mx
}

Received 10-IX-2001. C Corrected 14-XI-2005. Accepted 11-VIII-2006.

\begin{abstract}
We studied the time of initial sexual maturity and the fecundity of the goldfish Carassius auratus under semi-controlled conditions. During the study the water temperature fluctuated from 21 to $30^{\circ} \mathrm{C}$, the $\mathrm{pH}$ between 7 and 8, and the dissolved oxygen between 5.5 and $7 \mathrm{ppm}$. Sixty days old juvenile fish received prophylactic treatments of brackish water $(15 \%)$ and methylene blue baths (1\%), and they were fed with live Daphnia magna. The initial sexual maturity occurred between 225 and 233 days of captivity. Mean absolute fecundity was 2347 ( \pm 302.2 SD) ova per gonad, and mean relative fecundity was 63.44 eggs/g fish weight. Gonadosomatic index was between 7.5 and 9.0. Our data will allow ornamental fish producers to calculate the time of initial maturity and fecundity for this species. Rev. Biol. Trop. 54 (4): 1113-1116. Epub 2006 Dec. 15.
\end{abstract}

Key words: gold fish, Carassius auratus, initial maturity, fecundity.

One of the oldest of domesticated fishes is the goldfish Carassius auratus, the first aquarium fish. Its history as a pet goes back for many centuries. Originally from East Asia, it is called "wakin" in China, and "kin-yu" in Japan (Aries 1966). Matsubara presented a tropical fish culture in 1905 in Washington D.C. and described the reproduction of the lion head $C$. auratus (Axelrod 1976). Temperature changes are important to trigger spawning, which generally occurs from winter to spring (Axelrod and Burgess 1973).

Ornamental fish producers need to know the time of initial maturity, and the period of fecundity of the most important commercial species to predict their reproduction. We determined the time of initial sexual maturity and calculated fecundity of the goldfish $C$. auratus under semi-controlled conditions.

\section{MATERIALS AND METHODS}

This study was carried out near the Presidio River, Pozole, Sinaloa, Mexico, where there are ten cement tanks $3.0 \mathrm{~m} \times 1.5$ $\mathrm{m} \times 0.8 \mathrm{~m}$ for growing fish outdoors. The water temperature outdoors fluctuate from $21{ }^{\circ} \mathrm{C}$ in January and February to $30{ }^{\circ} \mathrm{C}$ in August and September, the $\mathrm{pH}$ between 7 and 8 , and the dissolved oxygen between 5.5 and $7 \mathrm{ppm}$. The rainy season lasts from July to September and the driest months are from April to June. The predominant winds are NW in winter and SW in summer with an average of $2.6 \mathrm{~m} / \mathrm{s}( \pm 0.5)$. Every ten days over 7 months water temperature was measured with a scale thermometer -20 to $110{ }^{\circ} \mathrm{C}$, oxygen was measured with a YSI-57 oxymeter accuracy and $\mathrm{pH}( \pm 1)$ measured 
with a Corning potentiometer. Rearing also took place under laboratory conditions.

Before the 60 days old juveniles were taken to the rearing site to mature they had a prophylactic treatment of brackish water of 15 $\%$ for $5 \mathrm{~min}$, then methylene blue baths (1\%) were used. Due to stress, the fish remained without food for the first $24 \mathrm{~h}$. Later, they were fed with live Daphnia magna.

Reproduction technique: $C$. auratus were fed live D. magna ad libitum. A pair of mature fish was introduced, together with three aquatic plants (Eichornia crassipes), for ova deposition site in a 4001 aerated container with filtered (10.5 and $0.5 \mu \mathrm{m}$ filters) and disinfected water treated with $0.25 \mathrm{ml}$ of commercial sodium hypochlorite (13\% active chlorine) for $24 \mathrm{~h}$, and $0.25 \mathrm{ml}$ of sodium thiosulfate $(10 \%$ normal solution) was added. After $12 \mathrm{~h}$, the ova were laid on the plant roots and fertilization had occurred. The aquatic plants with eggs were transferred to another aquarium of 401 . The eggs hatched after $48 \mathrm{~h}$ at $23{ }^{\circ} \mathrm{C}( \pm 1) ; 8.5$ ppm ( \pm 1.3$)$ was dissolved oxygen and $\mathrm{pH}$ was 7.5 , after hatch three to four more days they were free swimming.

The fish were weighed, their scales were separated from the ventral median line, and skin and muscle cut up to the anus to examine the coelomic cavity where the gonads were located. The sexual maturity method of Nikolsky (1963) was used, the scale 1. It is when the gonads are virgin. 2 to 4 . Gonads start development 5. Ripe gonad: before spawning occurs with a gentle pressure few ova came out, and 6 . It is a relaxing gonad. The gonads were weighed; the ripe ova were counted one by one using a magnifying glass. The gonadosomatic index was calculated from ripened fish by: GSI $=$ Wg100/Wt where GSI: gonadosomatic index, Wg: gonad weight $(\mathrm{g}), \mathrm{Wt}$ : total fish weight $(\mathrm{g})$. Absolute fecundity was calculated as the number of ripe ova found in the fish gonad, and relative fecundity was the number of ripe ova per gram of fish weight. The least squares method was used to develop predictive relationships among fish and gonad weight; fecundity indices were also calculated.

\section{RESULTS}

Increase of gonad weight, fish weight, gonadosomatic index, and Nikolsky scale in time to reach initial maturity is shown in Table 1. C. auratus reached initial sexual maturity at 225 days of age with a fish weight of $37.3 \mathrm{~g}$, gonad weight of $2.8 \mathrm{~g}$, and a gonadosomatic index of 7.5, according to the Nikolsky scale.

At initial sexual maturity, C. auratus reached a mean gonad weight of $3.15 \mathrm{~g}$, mean fish weight of $38.1 \mathrm{~g}$, mean absolute fecundity of 2547 ( $\pm 302.2 \mathrm{SD}$ ) ova per gonad. The maximum absolute fecundity was of 2921 ova per gonad (Table 2). In general, when the gonad is heavier, fish is heavier, and absolute and relative fecundity increase the number of ova. Since the results are from ten samples at the initial maturity stages the correlations show that the determination coefficient $\left(r^{2}\right)$ is low, because maturity is starting and the gonads are just developing, however according to the relationships shown in Table 3, the rate of absolute and relative fecundity increased when gonad and fish weight increased.

TABLE 1

Age, fish, and gonad weight, gonadosomatic index (GSI) and Nikolsky scale of C. auratus

$\begin{array}{ccccc}\text { Age in days } & \text { Fish weight }(\mathrm{g}) & \text { Gonads weight }(\mathrm{g}) & \text { G S I } & \text { Nikolsky scale } \\ 180 & 28.5 & - & - & 1 \\ 189-194 & 30.5-31.5 & 1.3-1.5 & 4.2-4.7 & 2 \\ 202-204 & 32.7-33.0 & 1.7-1.9 & 5.2-5.7 & 3 \\ 218-224 & 35.3-36.5 & 2.3-2.5 & 6.5-6.8 & 4 \\ 225-233 & 37.3-38.9 & 2.8-3.5 & 7.5-9.0 & 5\end{array}$


TABLE 2

Absolute and relative fecundity of $\mathrm{C}$. auratus, fish and gonad weight, and gonadosomatic index (GSI) at initial sexual maturity

\begin{tabular}{|c|c|c|c|}
\hline Absolute fecundity & Relative fecundity & Fish weight (g) & Gonad weight (g) \\
\hline 2347 & 61.6 & 38.1 & 3.2 \\
\hline 1936 & 60.0 & 37.3 & 2.8 \\
\hline 2367 & 61.4 & 38.5 & 2.9 \\
\hline 2058 & 52.9 & 38.9 & 3.5 \\
\hline 1955 & 50.1 & 39.0 & 3.0 \\
\hline 2370 & 64.4 & 36.8 & 3.4 \\
\hline 2426 & 64.52 & 37.6 & 3.4 \\
\hline 2536 & 66.21 & 38.3 & 3.2 \\
\hline 2556 & 66.22 & 38.6 & 3.1 \\
\hline 2921 & 77.0 & 37.9 & 3.7 \\
\hline Mean / 2547 & 62.44 & 38.1 & 3.15 \\
\hline S D / 302.2 & 7.4 & 0.79 & 0.28 \\
\hline Max / 2921 & 77 & 39 & 3.7 \\
\hline
\end{tabular}

Standard deviation (SD), and maximum value (Max).

TABLE 3

Several parameter relationships calculated by the least square method at initial sexual maturity of C. auratus

$\begin{array}{cccccc}\begin{array}{c}\text { Relationships (Independent.- } \\ \text { dependent) }\end{array} & \mathrm{a} & \mathrm{b} & \mathrm{r}^{2} & \mathrm{n} & \mathrm{P}<0.05 \\ \text { Fw - Gw } & -7.618 & 0.284 & 0.9 & 20 & 0.0000 \\ \text { Gw - Af } & -290 & 837.2 & 0.6 & 9 & <1.0 \\ \text { Af - Rf } & -3.405 & 0.0276 & 0.9 & 10 & <1.0\end{array}$

Absolute fecundity (Af), Fish weight (Fw), Gonad weight (Gw), Relative fecundity (Rf), Y-intercept (a), slope (b), determination coefficient $\left(\mathrm{r}^{2}\right)$, number of pairs $(\mathrm{n})$ and probability $(\mathrm{p}<)$.

\section{DISCUSSION}

Martty and Couto (1973) mentioned that Carassius developed well at temperatures between 18 and $25^{\circ} \mathrm{C}$. In our study the temperature fluctuated between 18 and $25{ }^{\circ} \mathrm{C}$. Temperature influences growth and gonad ripeness (Huet 1973). At $14{ }^{\circ} \mathrm{C}$, C. auratus maintain the last state of vitelogenesis and ovulation can be induced by increasing temperature to $20{ }^{\circ} \mathrm{C}$ (Harvey and Hoar 1980). Spieler et al. (1977) found that heat applied during the last
$4 \mathrm{~h}$ of darkness was particularly conducive to weight gain and gonad growth.

Swingle (1961) mentioned that a $\mathrm{pH}$ between 6.5 and 9 was adequate for reproduction in many fish species such as carp, striped bass and tilapia, but those around the Amazon River (such as discus and angelfish) preferred a $\mathrm{pH}$ lower than 7 (Axelrod 1976). The species in our study required a $\mathrm{pH}$ between 7 and 8 , which Huet (1973) also recommended.

Boyd (1989) mentioned that $C$. auratus survived at very low oxygen concentrations. Swingle 
(1961) confirmed that fish grew and reproduced from $5 \mathrm{mg} / \mathrm{l}$ up to oxygen saturation.

According to the Nikolsky (1963) method the maximum sexual maturity value reached by the gonads is 5 which was when the gonad fills up the coelomic cavity and coincides with the migration of the nucleus from the centre of the ovum to its periphery (Rodríguez 1992); in our study maturity was reached between 225 and 233 days old.

The species studied here was patch spawners, where ova had different grades of development, which could be in batches of different modal sizes (West 1990).

The initial sexual maturity gives to the ornamental fish producers the days when fish starts to be mature, thus they will prepare the reproduction and an appropriate nourishment environment for the fish to spawn and obtain the maximum number of fry, depending on how many female fish are required for this purpose. In general, heavier fish have heavier gonads, which produce more ova per fish gonad.

\section{ACKNOWLEDGMENTS}

We thank B. Martínez G., K. L. Moran S., L. Cervantes L. and A. Alamilla G. for their devoted participation in this work, and A. Nuñez P. and C. Ramírez for their collaboration.

\section{RESUMEN}

Estudiamos el tiempo inicial de madurez sexual y la fecundidad del pez dorado Carassius auratus en condiciones semi-controladas. Durante el estudio la temperatura del agua varió de 21 a $30^{\circ} \mathrm{C}$, el pH entre 7 y 8 , y el oxígeno disuelto entre 5.5 y 7 ppm. Jóvenes de 60 días de edad recibieron tratamiento profiláctico con agua salobre (15\%), y baños de azul de metileno (1\%). Se les alimentó con Daphnia magna. La madurez sexual inicial fue tras 225 a 233 días en cautiverio. La fecundidad absoluta media fue de 2347 ( \pm 302.2 DS) óvulos por gónada y la fecundidad relativa fue de 63.44 óvulos/g del peso del pez. El índice gonadosomático se calculó entre 7.5 and 9.0.

Palabras clave: pez dorado, Carassius auratus, madurez inicial, fecundidad.

\section{REFERENCES}

Aries, S.S. 1966. Ud. y el acuario. Albatros, Buenos Aires, Argentina. 480 p.

Axelrod, H.R. 1976. Breeding aquarium fishes. TFH, New York, USA. 480 p.

Axelrod, H \& L. Burgess. 1973. Breeding Aquarium Fishes Book 3. TFH, New York, USA. 197 p.

Boyd, C.E. 1989. Water quality management and aeration in shrimp farming. Fish and Shrimp. Allied. University of Alabama, Alabama, USA. 83 p.

Harvey, B.J. \& W.S. Hoar. 1980. Teoría y práctica de la reproducción inducida en los peces. CLL, Ontario, Canada. 48 p.

Huet, M. 1973. Tratado de piscicultura. Mundiprensa, Madrid, Spain. 753 p.

Martty, H. \& D.D.Couto. 1973. Peces tropicales. Albatros, Buenos Aires, Argentina. 129 p.

Nikolsky, G.V. 1963. The ecology of fishes. Academic, London, England. 352 p.

Rodríguez, G.M. 1992. Técnicas de evaluación cuantitativa de la madurez gonadal en peces. A G T. Editor. México, DF., México. 79 p.

Spieler, R.E., T.A. Noeske, V. de Vlaming \& A.H. Meier. 1977. Effects of thermocycles on body weight gain and gonadal growth in the goldfish, Carassius auratus Trans. Am. Fish. Soc. 106: 440-444.

Swingle, H.S. 1961. Relationships of $\mathrm{pH}$ of pond waters to their suitability for fish culture. Proc. Pac. Sci. Congr. 10: 72-75.

West, G. 1990. Methods of assessing ovarian development in fishes a review. Australian J. Mar. Fresh. Res. 41: 199-222. 